\title{
Compounded Perturbations Yield Ecological Surprises
}

\author{
Robert T. Paine, ${ }^{1 *}$ MiaJ. Tegner, ${ }^{2}$ and Edward A. Johnson ${ }^{3}$ \\ ${ }^{1}$ Department of Zoology, University of Washington, Seattle, Washington 98195, USA; 2Scripps Institution of Oceanography, \\ University of California, San Diego, La Jolla, California 92093-0201, USA; and ${ }^{3}$ Department of Biological Sciences \\ and Kananaskis Field Station, University of Calgary, Calgary, Alberta, Canada T2N IN4.
}

\begin{abstract}
A BStRACT
All species have evolved in the presence of disturbance, and thus are in a sense matched to the recurrence pattern of the perturbations. Consequently, disturbances within the typical range, even at the extreme of that range as defined by large, infrequent disturbances (LIDs), usually result in little long-term change to the system's fundamental character. We argue that more serious ecological consequences result from compounded perturbations within the normative recovery time of the community in question. We consider both physically based disturbance (for example, storm, volcanic eruption, and forest fire) and biologically based disturbance of populations, such as overharvesting, invasion, and disease, and their interactions. Dispersal capability and measures of generation time or age to first reproduction of the species of interest seem to be the important metrics for scaling the size
\end{abstract}

\section{INTRODUCTION}

All natural assemblages are perturbed by both physical and biological forces. These agents of change occur with different intensities, frequencies, and spatial distributions. Some essentially scour the landscape, resetting the successional clock to time zero. More commonly, disturbances leave a residual assemblage that provides a legacy on which subsequent patterns build. We consider the range of single perturbations, from small-scale/frequent disturbances to large/infrequent catastrophes, to be central to much traditional ecology; such directional

Received 14 J uly 1998; accepted 18 September 1998.

*Corresponding author; email: painert@zoology.washington.edu and frequency of disturbances among different types of ecosystems. We develop six scenarios that describe communities that have been subjected to multiple perturbations, either simultaneously or at a rate faster than the rate of recovery, and appear to have entered new domains or "ecological surprises." In some cases, three or more disturbances seem to have been required to initiate the changed state. We argue that in a world of ever-more-pervasive anthropogenic impacts on natural communities coupled with the increasing certainty of global change, compounded perturbations and ecological surprises will become more common. Understanding these ecological synergisms will be basic to environmental management decisions of the 21st century.

Key words: altered community states; dispersal; multiple disturbances; recovery intervals; scaling disturbances. or cyclical changes stimulated the development of ecology's first paradigm, succession (Cowles 1899; Clements 1905, 1916). A century of accumulated detail on the interplay between pattern and process has provided descriptors for the nature of successional change and system-dependent rates of recovery. There are few surprises embedded here: depending on the time frame of interest, species arrive and depart, canopies or other structures develop, and the system "recovers," converging on the predisturbance state at a rate reflecting the spatial extent and intensity of the disruptive forces. Such patterns have been extensively reviewed (Pickett and White 1985), and variation in recovery dynamics can be attributed to different processes acting independently or in concert (Drury and Nisbet 1973; Con- 
nell and Slatyer 1977). Even large, infrequent disturbances (LIDS) do not appear to override the biotic mechanisms that structure eventual recovery. For example, the 1988 Yellowstone National Park fire, which burned $36 \%$ of the park and was an order of magnitude larger than comparable large, infrequent fires, has to date generated no ecological surprises: "the postfire ecosystems are shaping up to be essentially the same as those that prospered before the flames" (Stone 1998: 1527). We argue that cycles of disruption and recovery are the usual state of affairs and submit that rapidly compounded perturbations have more serious implications for long-term alterations of community state, occasionally or even often generating a different assemblage of species.

Physical agents of change are well documented and described by such terms as windstorm, landslide, forest fire, flood, hurricane, and volcanic eruption. Many of these are primarily of terrestrial importance and leave their signature on landscapes as sites with recognizable boundaries and measurable shapes and areas. Biologically based counterparts-clear-cutting of terrestrial forests and trawling on the ocean floor-generate similar map properties. Populations are also subject to biological disturbances that vary from slight to catastrophic. Although these may lack spatially discrete boundaries, their implications for community structure can be at least as profound. Here we combine, when appropriate, biological disturbances like pestilence, population eruptions, invasions, and overharvesting with the more traditional physical forms of disturbance. In so doing, we add an animal and therefore a trophic dimension to a subject traditionally dominated by plant ecologists.

Figure 1 is a heuristic portrayal of our approach. In the top panel, a single large disturbance is followed by eventual return to some baseline condition at which point the assemblage can be considered "recovered." The diverse literature on succession is primarily concerned with this pattern and its underlying mechanisms. The following panels identify our focus. In the middle panel, two large disturbances are shown to occur nearly simultaneously or in close progression. We believe that recovery, if possible, is often substantially delayed under such conditions, and we provide examples below. In the bottom panel, a major disturbance is superimposed on an assemblage al ready maintained in an altered state, usually by anthropogenic processes. Current examples could include populations depressed by persistent overfishing, whole systems altered by chronic pollutants, or the developing impacts of climate change, such as the apparent increases in frequency and intensity of major storms

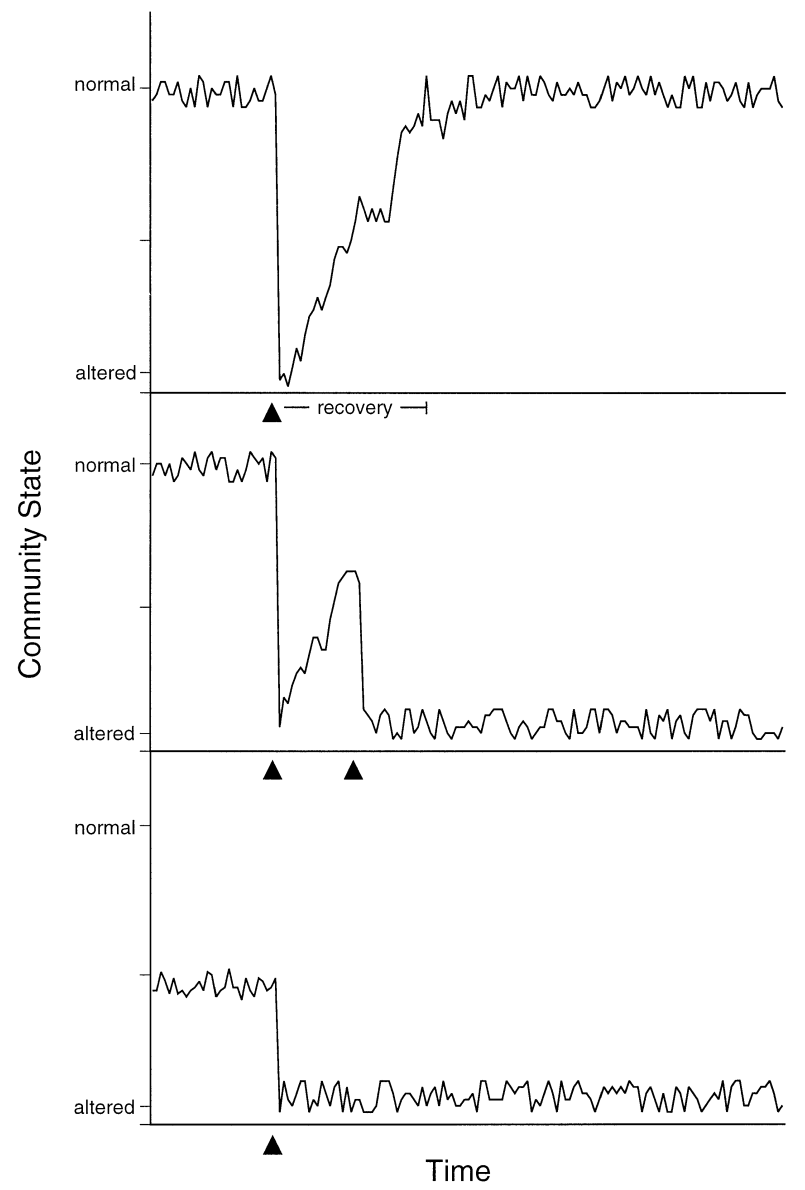

Figure 1. Schematic representation of the effects of large, infrequent disturbances (LIDs) on community state. Top, A normal community is subjected to a single LID and subsequently recovers. Middle, A normal community undergoes a second (or multiple) disturbance(s) before recovery from the first is completed; the combined effects lead to long-term alteration in community state. Bottom, A major disturbance is superimposed on an assemblage already already altered by anthropogenic processes or disease; again the combination of stresses leads to longterm alteration of comunity state. Arrowheads mark the disturbances.

and other climate extremes with increasing temperatures [for example, see Flavin (1996)]. J ansson and Velner (1995: 332), for example, suggest that in the Baltic Sea, a brackish body of water with minimal connection to the North Sea, which has been heavily impacted by eutrophication and toxic inputs, "pollution has reached the point where damage may be irreversible."

The scenarios discussed next include systems that appear, albeit temporarily, to have entered a new ecological domain; that is, they have not recovered. They share two features in common. First, all have been subjected to large (based on duration or spatial 
magnitude) and severe (quantified as a major mortality event) perturbations that may be physical or biological in origin. Second, these have occurred either simultaneously or in a sequence rapid enough that recovery from the single pulse has not significantly progressed. In some instances, three or more pulses appear to benecessary to initiate the changed state. Another way to describe our concern is to recognize that the community effect of compounded perturbations is multiplicative, not additive. If true and general, ecological surprises should be increasingly commonplace, prediction of recovery rates and trajectories less certain, and management more difficult.

\section{Quantifying Disturbances AND Their Frequencies}

We adopt the definition of disturbance used by White and Pickett (1985: 7): "A disturbance is any relatively discrete event in timethat disruptsecosystem, community, or population structure and changes resources, substrateavailability, or the physical environment." Pickett and White (1985) make the point that disturbances span three orders of magnitude of time (years) and ten of space $\left(\mathrm{m}^{2}\right)$. Disturbances, while causing spatially identifiable mortality to some species, usually provide open or invadable space for others, often renewing resources in the process. Sometimes, they can be identified by the resultant patchiness, recognizable by shape, size, postdisturbance internal composition, and spatial distribution. These patterns also have a dynamic, especially frequency of formation and rate of return toward the predisturbance state. Turner and colleagues (1997) suggest that it is also necessary to recognize the roles that individuals or species surviving a disturbance event can play in mitigating the event's impact. They suggest that only events characterized by few "residuals" be considered as large. We concur.

Disturbances can mean high mortality, often death of all individuals in the disturbance area. LIDs have different meanings for different ecosystems. For example, a large disturbance in the tidal zone may be on the order of tens of square meters, whereas in a forest it may be thousands. Hence, some scaling relationship must be used to ensure that these terms have equivalent meanings between systems. If, for example, we choose population dynamics as the processes of interest, disturbance size and frequency could be scaled by birth, death, or immigration (dispersal). Dispersal seems a particularly significant scaling metric for it governs the rate of recolonization of the disturbed site. Thus, ruderal (fugitive) species are typically both early invaders and excellent dispersers. Greene and J ohnson (1989) applied a scaling metric involving seed terminal velocity, height of seed release, and mean horizontal wind speed to make dispersal comparable between species with different characteristics. For instance, ashfall accompanying the eruption of Mount St. Helens in 1980 greatly reduced many insect and spider populations. Because adult female leafhoppers (Errhomus) lack long-distance dispersal, they were slow to return to preeruption abundances in contrast with spiders (Showalter 1985). Similarly, on rocky marine shores, the poorly dispersing brown alga Postelsia can be driven locally extinct (Paine 1988 and unpublished), whereas local extinction ishighly improbable for the associated barnacle Balanus glandula, whose larvae can traverse hundreds of kilometers. Thus, defining when a disturbance is large depends on the interplay between the spatial magnitude of the area disrupted and the dispersal (reinvasion) ability of the species of interest. Similarly, the frequency of disturbance could be scaled by some measures of generation time or age of first reproduction. In contrast, scaling on the basis of size of the dominant organisms does not appear to be a useful metric; for example, consider giant kelp (M acrocystis pyrifera) and terrestrial trees: sizes are comparable but time scales for age to first reproduction and life spans differ by orders of magnitude.

Ecological evidence seems to indicate that most LIDs do not override the biotic mechanisms governing species composition: in many disturbances, the postdisturbance composition is similar to the predisturbance composition (Turner and others 1997). This result might have been anticipated if size and frequency of disturbance had been scaled in terms of dispersal distances and generation times instead of the quantity of hectares and years as usually used.

Two other kinds of disturbances lack spatially explicit features but can have equally significant consequences: (a) Populations can be thinned commercially or reduced to mere vestiges of their original abundances by disease. For example, the majority of commercial fish stocks in US and Canadian coastal waters have been overexploited or are currently at maximum sustainable yield levels (NOAA 1993). Rinderpest decimated herds of African ungulates, especially buffalo (Sinclair 1977). The community changes resulting from density shifts of dominating species, often of high trophic status, can be extensive. They are a biologically based disturbance and often leave no immediate spatial signature. (b) Global climate change, a more cosmic form of disturbance, will surely have a 
substantial though currently unquantified and debated impact. It will provide a background of change in which both physical (for example, fire) and biological (for instance, harvesting and disease) disruptive forces will operate, and it might become the dominant influence on community structure and change in the coming decades despite its subtlety.

When do changes in community composition occur or under what conditions can they be anticipated? We believe that such dramatic shifts are most likely when both the spatial extent and especially frequency of disturbance are at the extremes of normal expectations. Multiple, usually sequential occurrences of these extreme and rare events can produce alternative stable states, that is, abnormal conditions or ecological surprises that defy the norm. The following scenarios describe communities that have been subjected to multiple perturbations and appear to have entered (or be facing) new domains.

\section{Compounded Perturbations IN ECOLOgical TIME}

\section{El Niños, Storms, and Kelp Bed Recovery}

El Niño-Southern Oscillation (ENSO) events are large-scale oscillations of the tropical Pacific Oceanatmosphere system with far-reaching climatic and economic impacts. The 1982-83 El Niño was widely considered the strongest of the century and had a corresponding impact on forests of giant kelp along the coasts of Alta and Baja California. Winter 1982-83 was the most severe storm season in many decades, as atmospheric teleconnections linked to the warming of the eastern equatorial Pacific Ocean affected the Aleutian low-pressure center, generating a large number of severe storms from an unusual southerly direction. These storms devastated kelp forests throughout the range of Macrocystis pyrifera, an economically valuable kelp. Anomalous poleward flow of warm, oligotrophic waters that rendered upwelling ineffective led to nutrient depletion, massive loss of kelp biomass, and extensive summer mortality in the southern half of $M$. pyrifera's range. The severity of the warm-water effects was related to latitude. In South America, anomalies were as high as $11^{\circ} \mathrm{C}$ during 1982-83; there was mass mortality of $\mathrm{M}$. integrifolia and associated animal populations in Peru and northern Chile (Dayton and Tegner 1990). In the southernmost part of the range in Baja California, giant kelp went extinct in some areas and site preemption by lower standing kel ps prevented its recovery after the ENSO.

In the San Diego region, the combined effects of the storms (ENSOs can be storm free) and the $4^{\circ}-5^{\circ} \mathrm{C}$ warm-water anomalies constituted the most severe disturbance of a giant kel p forest community ever documented, yet recovery was rapid once conditions returned to normal (Tegner and Dayton 1987; Dayton and others 1992). At the other end of the range in central California, the intensity and duration of the warm event were smaller and conditions remained within the suitable range for kelp [reviewed by Tegner and Dayton (1987), Dayton and Tegner (1990), and Dayton and others (1992)]. Kelps are well adapted to winter-storm disturbance, with correspondingly timed reproduction, spore dispersal tied to water movement, and success of the propagules a function of open space. The more problematic warm-water effects result from the severity and duration of the events and probably the frequency, as well.

ENSOs are natural climate variations to which communities have been subjected for at least hundreds of years, but there are major questions about whether the intensity and/or frequency of these events may change as a result of global warming (Trenberth 1995). The observational record indicates that ENSO events have changed in frequency and intensity in the past century, but the frequency of strong events appears unchanged back to 1625 (Enfield 1988). Coupled ocean-atmosphere general circulation models find that ENSOs will continue to exist in a warmer world, but have yet to address frequency and intensity. Trenberth (1995) suggests that because these events have the effect of creating droughts and floods in different parts of the world and global warming tends to enhance the hydrological cycle, there is a real prospect that future ENSOs will be accompanied by more severe droughts and floods. For Northern Hemisphere kelp forests, the question may be whether ENSO thermal additions to already warmer water conditions [for example, see Roemmich and M cGowan (1995)] in the future can push kelps beyond the range of recovery, especially in the southern end of the range.

\section{Climatic Extremes and Exotic Species in San Francisco Bay}

San Francisco Bay, at the mouth of rivers draining $40 \%$ of California, is considered to be the major estuary in the United States most modified by human activity (Nichols and others 1986). Many alterations of the ecology and the bay, such as loss of habitats, water-quality changes, introduced species, and excessive freshwater diversion, date to the 19th century, yet recent disturbances have led to profound changes. In late 1986, the euryhaline Asian bivalve mollusc Potamorcubula amurenis was first sampled in San Francisco Bay (Carlton and others 
1990; Nichols and others 1990). Within 2 years, it had spread throughout the estuary, on all sediment types and water depths, and reached densities at some sites exceeding $10,000 \mathrm{~m}^{-2}$. This invasion almost certainly resulted from the discharge of seawater ballast from cargo vessels.

Two years of climatic extremes apparently contributed to this remarkable population explosion (Nichols and others 1990). Before P. amurensis was discovered, the benthic community in Suisun Bay (northern region of the bay) varied predictably with river inflow: years of normal or high flow were characterized by brackish or freshwater species, and years of low flow by estuarine species. The end of the 1984-85 dry event was marked by an extreme but short-lived flood that eliminated the estuarine species. Thus, when P. amurensis was introduced, the Suisun Bay region was inhabited by a disturbed and depauperate community that may have contributed to the initial success of the invader. The invader's timing after the flood guaranteed it months to exploit the available space before the dry-period species would return, and by 1988 the near absence of the dry-period community demonstrated how well P. amurensis had displaced the former community. The ability of the invader to live in low-salinity water suggests that it will not be displaced with the return of normal river flow and that the benthic community is permanently altered (Nichols and others 1990).

Carlton and colleagues (1990) predicted significant community changes as this abundant consumer, competitor, disturber, and prey altered the interactive trophic webs in San Francisco Bay; these are beginning to unfold. Within a year, chlorophyll concentration and adult abundance of three common copepod species had declined by $53 \%-95 \%$; these values persisted through 5 years of study (Kimmerer and others 1994). Before 1987, chlorophyll concentration varied with river flow; after mid-1987, it remained low despite variations in flow. The effect on copepods appears to be via direct clam predation on nauplii; egg production was not affected. Estimates of clam clearance rates are consistent with the reduction in copepod abundance. Although it may be premature to forecast permanent changes in the zooplankton populations, Kimmerer and colleagues (1994) voice serious concern: several species of fish that pass their larval lives in the upper estuary are also in serious decline. Moyle and coworkers (1992) list five species, including those in valuable sport and commercial fisheries, in which poor first-year classes correlate with reduced freshwater outflow, presumably because of decreased survival of larvae and juveniles. A sixth, the delta smelt, which is federally listed as threatened, feeds primarily on copepods, has a narrowly defined habitat in the mixing zone between fresh and salt waters, is an annual species very sensitiveto environmental fluctuations, and has declined in concert with increasing water diversions since 1984 (Moyle and others 1992). Thus, the compounded effects of two major disturbances-one biological (the successful establishment of a nonindigenous species) and the other physical (drought followed by an extreme flood)-have initiated sweeping and probably permanent changes in ecosystem structure.

\section{Boreal Forest Wildfires, Forest Fragmentation, and Logging}

Fire frequency in the boreal forest is primarily controlled by large-scale climate processes, specifically persistent midtropospheric anomalies that at the surface are expressed as blocking high pressures (Schroeder and others 1964; Newark 1975; Street and Birch 1986; Flannigan and Harrington 1988; Johnson and Wowchuk 1993). In this century, however, agricultural settlement in the southern fringe of the boreal forest and logging further north have resulted in a new multiple-disturbance regime that has caused significant changes in forest composition.

In the last three centuries, fire frequency in the boreal forest has changed several times, each time associated with large-scale climatechanges (J ohnson 1992). The changes in the early 1700 sand the 1800 s were a result of the Little Ice Age (Grove 1988). In the boreal forest, this period had more frequent fires than the periods before or since (Bergeron and Achambault 1993). These changes in fire frequency appear to be associated with increased numbers and length of persistent midtropospheric anomalies. Years with large areas burned are known to have more sequences of days during the fire season with warmer, drier weather, which are associated with upper-level ridges. These persistent upper-level ridges over the boreal forest are teleconnected (spatially and temporally correlated) to upper-level troughs in the North Pacific and eastern North America. This teleconnection is called the Pacific North America pattern (Rogers 1981; Wallace and Gutzler 1981; Knox and Lawford 1990; Johnson and Wowchuk 1993). Similar patterns have been described in the southwestern United States as a result of ENSOs (Swetnam and Betancourt 1990).

The transition periods between different fire frequencies, for example, at the end of the Little Ice Age, seem to have been periods in which fires occurred more erratically for a decade or more. Often these periods were marked by clusters of 
years with very large areas burned and many persistent upper-level ridges. One could speculate that the large areas burned in the boreal forest since the 1980s are a result of one of these transition periods, perhaps related to global warming. However, more understanding of these transient processes is required before anything definitive can be said.

These climate-driven changes in fire frequency have generally been part of the ecosystem dynamics of the boreal forest for millennia. In this century, two new classes of large-scale disturbances were added to the climate-driven fire frequency. These anthropogenic forces were agricultural settlement in the southern boreal forest and logging.

Homesteading in the early 1900 s led to progressive clearance of forest in the southern fringe of the boreal forest in western Canada (Vanderhill 1958). The effect on the forest north of the fringe was to increase the frequency of fires above that of the natural lightning fire regime. The increase was due to escaped clearance fires spreading from the settlement areas north up to $50-60 \mathrm{~km}$ into the unsettled forest. The result of this major increase in fires meant that trees that required longer time to reach sexual maturity, did not have serotinous cones, had little or no vegetative reproduction potential, were greatly reduced in abundance, and in many areas were locally exterminated (Weir 1996). For example, white spruce (Picea glauca) and balsam fir (A bies balsamea) both became relatively unimportant trees in many forests and trembling aspen (Populus tremuloides) significantly increased in abundance. Also, change from a mixed-wood (coniferdeciduous) to primarily deciduous forest has caused many other changes in plant and animal species (Weir 1996). At the same time that this forest was being subjected to an increase in the frequency of fire, high-grade logging (cutting of only large trees) of the white spruce was further reducing this dominant boreal species.

The southern boreal forest today has a significantly different composition than it did a century ago. This change has been due to multiple perturbations: a natural lightning fire regime augmented by settlement fires spreading from adjacent areas and logging.

\section{Early Succession and Exotic Species}

Volcanic eruptions clearly embrace the concept of disturbance, either by presenting new landscapes and initiating primary successional processes, or by altering preexisting ones via ashfalls, pyroclastic scorching, and the like. The end result of the recovery/regeneration process seems fairly predict- able: Turner and colleagues (1997) compare the assembly of the plant community on Mount St. Helens (WA) following its 1980 eruption with other single large infrequent disasters. On this barren landscape, some degree of successional uncertainty may well characterize the early stages of the recovery process. Morris and Wood (1989) found in experiments on lupine, a nitrogen-fixing pioneer species, evidence that two other invaders could be either facilitated or inhibited. Such stage dependency complicates the successional process; it probably does not alter the ultimate community composition, although insufficient time has elapsed since the eruption to evaluate the consequences of these initial uncertainties.

The Hawaiian Islands are also of volcanic origin and, despite being earth's most isolated archipelago, have been invaded by 4600 exotic plants, 86 of which represent serious threats to the native ecosystem (Vitousek 1990). The successful invasion of a nitrogen-fixing exotic (Myrica faya) on the slopes of Hawaii Volcanos National Park provides a classic example. A 1959 eruption deposited 1-2 m of ash on the native vegetation, thinning it substantially. Myrica invaded and initiated a series of changes including the identity of the dominant tree, nutrient cycling, and productivity. For instance, Woodward and coworkers (1990) showed that native Hawaiian birds, while visiting Myrica, rarely feed on its fruit. Nonnative species visited, fed, and effectively dispersed viable seeds. M yrica itself is fecund: Vitousek and Walker (1989) estimate the seed rain at 4.6 million/ha under 21 adult Myrica/ha. In addition, the mean adult growth of these invaders is approximately 15 times that of a native tree (Vitousek and Walker 1989). M yrica is quadrupling theinput of soil nitrogen (Vitousek 1990); earthworms are 2-8 times as dense under it than under native vegetation, which will change litter-processing dynamics and the rate of accumulation of soil organic matter (Aplet 1990).

As Vitousek (1990; Vitousek and Walker 1989) has demonstrated, the changes in whole ecosystemlevel function are substantial. One major speculation is that when, or if, Myrica is replaced during primary succession, it will be replaced by another exotic. The competitively aggressive strawberry guava is a likely candidate species. Because, in general, sites with more fertile soils - higher concentrations of soil nitrogen in a system where $\mathrm{N}$ is a limiting resource-are conducive to invasion, "nitrogen fixation by Myrica will ultimately favor invasion by a broader range of exotic species" (Vitousek and Walker 1989: 261). Finally, as these authors note, invasion changes the ground rules governing coex- 
istence of native assemblages recovering from or responding to disturbance. The problem is of great pragmatic importance to conservation biology: it further signals the existence of surprises at ecosystem levels when disturbances, in this case volcanism and biological invasion, are compounded.

\section{Hypoxia in the Northern Gulf of Mexico}

Oxygen depletion, long known from confined bodies of water, such as basins, fjords, bays, and estuaries, is increasingly reported from coastal ocean environments (Boesch and Rabalais 1991; Diaz and Rosenberg 1995). This may take the form of anoxia, where dissolved oxygen concentrations are essentially zero and hydrogen sulfide (toxic to metazoans) is detectable, or more commonly hypoxia, where oxygen concentrations on the sea floor are reduced to levels low enough to cause severe stress and mass mortality of benthic and water-column fauna. Varying with the severity of the oxygen depletion, effects on the biota range from avoidance of the affected area, to mortality of more sensitive taxa such as crustaceans and echinoderms, to emergence of the redox potential discontinuity from the sediments, a condition where only chemoautotrophic bacteria can live. Diaz and Rosenberg (1995) report that no other variables of such ecological importance to coastal marine ecosystems have changed so drastically in such a short period of time. Increasing evidence of oxygen depletion in coastal ecosystems is associated with anthropogenic eutrophication and, when eutrophication is coupled with adversemeteorological and/or hydrodynamic events, hypoxic events increase in frequency and intensity.

The inner and middle continental shelf of the northern Gulf of Mexico from the Mississippi River Delta to Texas is the largest and most severely affected area in North America subject to seasonal hypoxia [operationally defined by dissolved oxygen levels less than $2 \mathrm{mg} / \mathrm{L}$ or less than $1.4 \mathrm{ml} / \mathrm{L}$ (Rabalais and others 1991)]. From 1985 to 1988, hypoxic waters were found from April to October, from 5 to $60 \mathrm{~m}$ water depth, from 5 to $60 \mathrm{~km}$ offshore, extended up to $20 \mathrm{~m}$ above the bottom, and covered up to $9500 \mathrm{~km}^{2}$. Hypoxia in this region is coincident with strong, salinity-controlled stratification during the warmer months of the year, which restricts reoxygenation of the bottom waters. Large quantities of decomposing phytoplankton biomass fueling intense water-column and benthic respiration rates enhance the effects of stratification on oxygen depletion. Although hypoxia did not cause extensive mortalities on the northern Gulf of Mexico shelf until 1978, it has occurred almost annually since it was first discovered in 1973 (Diaz and
Rosenberg 1995). Severity and extent vary interannually with river flow, shelf circulation, and tropical storm mixing (Rabalais and others 1991).

The importance of the extent and duration of the hypoxia on the Louisiana shelf relates to fishery landings from this state, which constitute $28 \%$ of the US total (Rabalais and others 1991). Abundances of finfish, shrimp, and swimming crabs are severely depressed in hypoxic areas, and the period of oxygen stress includes critical life-history periods of several commercially important species. The macrofauna either succumb or move to avoid stressful conditions; typically, demersal species have been observed high off the bottom where mortality due to predation is undoubtedly high (Boesch and Rabalais 1991). When hypoxia persists, only highly resistant taxa such as some polychaetes and nematodes survive. Posthypoxia community dynamics depend on the extent of the mortalities, age of affected populations, timing with respect to availability of recruits, size of the affected area relative to shortdispersal recruits, frequency of hypoxic stress, and degree of organic carbon buildup. Because of the recurrent nature of hypoxia in the northern Gulf of Mexico, there are few large or long-lived sedentary species, and the benthic community is dominated by opportunistic species characteristic of an early successional state (Boesch and Rabalais 1991; Diaz and Rosenberg 1995). Intensified commercial fishing on the continental shelf in the 1970s and 1980s has been accompanied by alarming declines in the estimated sizes of remaining fish stocks; although overexploitation isclearly important, Darnell (1992) suggests that habitat deterioration is affecting both nursery areas and food chains for commercial species.

The Mississippi River and its distributaries drain $40 \%$ of the coterminous United States. Nitrogen concentrations in the rivers, the major source of "new" nutrients to the offshore phytoplankton, have more than doubled since the mid-1950s (Rabalais and others 1991). Turner and Rabalais (1994) recently demonstrated a close coupling between riverine loading and phytoplankton production; changes in biologically bound silica in the sediments below the river plume were virtually coincident with increases in nitrogen loading. After major flooding in 1993, the Gulf of Mexico hypoxic zone doubled to $18,000 \mathrm{~km}^{2}$ and has not shrunk much since (Kaiser 1996). On 12-13 August 1996, winds forced oxygen-depleted water from the offshore dead zone below the mouth of the Mississippi River close to shore. This caused a "jubilee" along $36 \mathrm{~km}$ of Louisiana coastline, a condition where shrimps, crab, and finfish crowd close to shore to escape the 
oxygen-deficient water-highly increasing their susceptibility to fishing (Buck 1996). Kaiser (1996) reports that the US federal government may be finally waking up to warnings that the Gulf of Mexico hypoxic or "dead zone" may be one of the nation's worst ecological problems. A multiagency committee has been convened to discuss the problem and recommend management steps, such as voluntary reductions in fertilizer use in the Midwest. Again, compounded perturbations-coastal eutrophication exacerbated by extrememeteorological events-have produced an altered community state.

\section{Phase Shifts in Jamaican Coral Reefs}

Like all communities, coral reefs are subject to occasional intense natural disturbances: plagues of the starfish A canthaster (Birkeland 1982), hurricane devastation (Woodly and others 1981), and high temperature stress (Gates 1990). Long-term studies of reef structure along a depth gradient at Discovery Bay, J amaica, provide a clear and sobering view of phase shifts in assemblage structure associated with a compounded series of severe disturbances.

Baseline data at the main site exist from the 1950s (Goreau 1959), and the site has been repeatedly examined quantitatively since then (Andres and Witman 1995). A sequence of events initiated in the early 1980s, but set against a subtler background of increasing coastal pollution and extreme harvesting pressures on herbivorous fishes, has led to what Hughes (1994) calls "large scale degradation" and vividly portrays as a phase shift in community structure. Depending on the depth at which corals are sampled, percent cover has decreased from 30\%-60\% in 1977 (Huston 1985) to approximately 5\% at depths less than $30 \mathrm{~m}$ in 1992 (Andres and Witman 1995). Conversely, algal cover, accounting for less than 5\% cover in 1982, comprised approximately $70 \%$ cover in 1992. As a result of algal preemption of space, larval recruitment of all corals failed after 1984 (Hughes 1994).

The compounded disturbances-two major hurricanes (Allen in 1980 and Gilbert in 1988) and mass mortality of an ecologically significant grazer, the sea urchin Diadema, from 1982 to 1984-occurred well within the normal recovery interval of reefs. Hughes (1994) suggests that reef regeneration was initiated shortly after Hurricane Allen despite reduced grazing fish populations. The Diadema dieback delivered the coup de grâce and the recovery trend was reversed. Andres and Witman (1995) suggest that Hurricane Gilbert only slowed the developing domination of al gae and therefore failed to enhance coral recovery. Furthermore, these au- thors imply that if urchin and fish populations had retained their pre-Allen levels, coral recovery and domination of the benthos would have occurred. With continued depression of herbivore populations, recovery of the coral assemblage is not forseeable.

In this case, a variety of disturbances, occurring rapidly relative to coral regeneration capacity, have yielded a novel community state-one that would not have developed if the disturbance events had occurred individually at intervals appropriate for reef recovery.

\section{Discussion}

A world of ever-more-pervasive anthropogenic impacts on natural communities coupled with the increasing certainty of climatic response to human activities suggests that compounded perturbations and ecological surprises will become more common. The frequency of disturbances is often scaled in terms of severity and return intervals: for example, the 30-year flood or the 100-year storm. The large number of record weather events in the news in recent years raises the issue of climate change and its interactions with LIDs. We reiterate our belief, and concern, that ecologists must refocus their interest from the ordinary (for instance, recovery sequences between normally spaced disturbances) to the extraordinary (for example, rapid sequential disturbances occurring against a background of increasing climate change).

We do not question the capacity for single LIDs to distort ecosystem structure and functioning temporarily. They obviously do, and merit investigation in their own right. On the other hand, the ecological literature is replete with underappreciated studies of compounded disturbances. Here we identify two more to suggest their ubiquity. Zedler and colleagues (1983) describe the interaction of fire and an annual grass planted to control erosion. Their conclusion that (p. 817) "We doubt if traditional climax-oriented successional theories can be of much use in predicting the outcome" resonates with our theme. In addition, several of the case histories developed in Gunderson and coworkers (1995) suggest that maladaptive management actually decreases ecosystem resilience, thus increasing susceptibility to subsequent disturbances, perhaps even facilitating disturbances and thwarting effective management.

The 1995 Intergovernmental Panel on Climate Change report (IPCC) (Houghton and others 1996), the international consensus summary of climate science, reviews the low probability that observed 
changes could be caused by natural factors alone, the average rate of warming for the 21st century that is likely to be warmer than any seen in the last 10,000 years, and projections for sea-level rise. Globally, existing data do not offer statistical evidence that extreme weather events or climate variability have increased in the 20th century, although there is clear evidence on regional scales. The IPCC review of model results finds agreement on predictions of general warming with regional variability and an enhanced global mean hydrological cycle. Regional forecasts are more problematic, but the incidence of floods, droughts, fires, and heatwaves is expected to increase in some areas and decrease in others as temperatures rise (Houghton and others 1996).

Our scenarios were chosen to identify the range of possibilities and the resulting ecological surprises. We have made no attempt to be encyclopedic. Rather, our list is characterized by events with blurred or no discernible borders, except as dictated by local geography (San Francisco Bay, for example) or study at a specific location (for example, Jamaica). Missing entirely are those great disturbances with sharp spatial boundaries as often characterize tornado paths or intertidal mussel-bed destruction. Missing also are references to the human condition, for instance, the interplay between malnutrition and disease. The growing evidence for unusual meteorological events leading to outbreaks of disease infectious among humans, such as hantavirus, cholera, and plague (Linden 1996), provides numerous examples. In one well-studied case, Colwell (1996) relates the massive cholera pandemic that struck South America in 1991 to the transport of zooplankton in a freighter's ballast water to the coast of Peru at the onset of an El Niño event. The El Niño brought rain and the influx of nutrients from land as well as warm sea surface temperatures, factors associated with the initiation of plankton blooms. This El Niño event, which lasted from 1990 to June 1995 and is the longest on record since 1882, may also be associated with the cholera bacterium remaining endemic in the region (Colwell 1996).

Present and future global climate-change effects on the environment may be debatable, but this is not the case for increasing human impacts: population growth, urbanization, deforestation, eutrophication, overfishing, loss of habitat, and so on. In ironic contrast with many political leaders, the insurance industry has recognized the significance of the nexus of these issues. Faced with rapidly escalating insured costs for increasing numbers of severe catastrophes over the last decade, that indus- try is realizing that it must demand political action to protect the climate to prevent its own financial ruin (Flavin 1996; Munich Re 1996). Our perspective is that societies and ecologists must begin to prepare themselves for novel and unanticipated consequences of previously well-understood phenomena. Jamaican coral reefs may not recover, Hawaiian volcanic slopes may develop a novel flora, and San Francisco Bay appears to be acquiring a new and not necessarily desirable invertebrate assemblage, in the process losing native species. Global warming may accelerate the effects of oxygen deficiency and enlarge affected areas in the Gulf of Mexico. These altered and possi bly alternative states (Lewontin 1969; Sutherland 1974) may or may not be persistent (stable). On the other hand, mounting evidence suggests that sequential, large-scale disruption of the current state will make these altered statesthe ecological reality of the future. Understanding the role of compounded disturbances, some natural and others of anthropogenic origin, will be basic to environmental management decisions in the 21st century.

\section{ACKNOWLEDGM ENTS}

We thank M. Turner and V. Dale for their invitation to participate in the Large Infrequent Disturbance workshop, A. Sun for the graphics, R. Somerville for references, and C. D. Canham, S. R. Carpenter, V. Dale, P. Dayton, C. Peterson, and M. Turner for their comments on the manuscript. This work resulted from a workshop (LIDs) conducted at the National Center for Ecological Analysis and Synthesis, a center funded by the National Science Foundation (grant DEB-94-21535), theUniversity of CaliforniaSanta Barbara, and the State of California.

\section{REFERENCES}

Andres NG, Witman JD. 1995. Trends in community structure on a J amaican coral reef. Mar Ecol Prog Ser 118:305-10.

Aplet GH. 1990. Alteration of earthworm community biomass by the alien Myrica fava in Hawaii. Oecologia (Berl) 82:414-6.

Bergeron Y, Achambault S. 1993. Decreasing frequency of forest fires in the southern boreal zone of Quebec and its relation to global warming since the end of the "Little Ice Age." Holocene 3:255-9.

Birkeland CE. 1982. Terrestrial runoff as a cause of outbreaks of Acanthaster pland (Echinodermata: Asteroidea). Mar Biol 69: 175-85.

Boesch DF, Rabalais NN. 1991. Effects of hypoxia on continental shelf benthos: comparisons between the New York Bight and the Northern Gulf of Mexico. In: Tyson RV, Pearson TH, editors. Modern and ancient continental shelf anoxia. p 27-34. (Geological Society Special Publication 58.)

Buck G. 1996. Marine fisheries information summary for United States Congress and Staff, 16 August 1996 [Downloaded from the Internet]. 
Carlton JT, Thompson JK, Schemel LE, Nichols FH. 1990. Remarkable invasion of San Francisco Bay (California, USA) by the Asian clam Potamocorbula amurensis. I. Introduction and dispersal. Mar Ecol Prog Ser 66:81-94.

Clements FE. 1905. Research methods in ecology. Lincoln (NE): University.

Clements FE. 1916. Plant succession: an analysis of the development of vegetation. Carnegie Inst Washington Publ 242:1-512.

Colwell RR. 1996. Global climate and infectious disease: the cholera paradigm. Science 274:2025-31.

Connell JH, Slatyer RO. 1977. Mechanisms of succession in natural communities and their role in community stability and organization. Am Nat 111:1119-44.

Cowles HC. 1899. The ecological relations of the vegetation on the sand dunes of Lake Michigan. Bot Gaz 27:95-117.

Darnell RM. 1992. Ecological history, catastrophism, and human impact on the Mississippi/Alabama continental shelf and associated waters: a review. Gulf Res Rep 8:375-86.

Dayton PK, Tegner MJ . 1990. Bottoms beneath troubled waters: benthic impacts of the 1982-84 El Niño in the temperate zone. In: Glynn PW, editor. Ecological consequences of the 19821983 El Niño to marine life. Amsterdam: Elsevier. p 433-72. (Elsevier Oceanography Series 52.)

Dayton PK, Tegner MJ , Parnell PE, Edwards PB. 1992. Temporal and spatial patterns of disturbance and recovery in a kelp forest community. Ecol Monogr 62:421-45.

Diaz RJ , Rosenberg R. 1995. Marine benthic hypoxia: a review of its ecological effects and the behavioral responses of benthic macrofauna. Oceanogr Mar Biol Ann Rev 33:245-303.

Drury WH, Nisbet ICT. 1973. Succession. J Arnold Arbor Harv Univ 54:331-68.

Enfield DB. 1988. Is El Niño becoming more common? Oceanography 59:123-7.

Flannigan MD, Harrington JB. 1988. A study of the relation of meteorological variables to monthly provincial area burned by wildfire in Canada (1953-1980). J Appl Meteorol 27:441-52.

Flavin C. 1996. Facing up to the risks of climate change. In: Starke L, editor. State of the world 1996. New York: WW Norton. p 21-39.

Gates RD. 1990. Seawater temperature and sublethal coral bleaching in J amaica. Coral Reefs 8:193-7.

Goreau TF. 1959. The ecology of J amaican coral reefs. I. Species composition and zonation. Ecology 40:67-90.

Greene DF, Johnson EA. 1989. A model of wind dispersal of winged or plumed seeds. Ecology 70:333-47.

Grove J M. 1988. The little ice age. New York: Methuen.

Gunderson LH, Holling CS, Light SS, editors. 1995. Barriers and bridges to the renewal of ecosystems and institutions. New York: Columbia University Press. $593 \mathrm{p}$.

Houghton JT, Meira FIIho LG, Callander BA, Harris N, Kattenberg A, Maskell K. 1996. Climate change 1995. World M eteorological Organization/Intergovernmental Panel on Climate Change. Cambridge: Cambridge University Press.

Hughes TP. 1994. Catastrophes, phase shifts, and large-scale degradation of a Caribbean coral reef. Science 265:1547-51.

Huston M. 1985. Patterns of species diversity in relation to depth at Discovery Bay, J amaica. Bull Mar Sci 37:928-35.

J ansson BO, Velner H. 1995. The Baltic: sea of surprises. In: Gunderson LH, Holling CS, Light SS, editors. Barriers and bridges to the renewal of ecosystems and institutions. New York: Columbia University Press. p 292-372.
Johnson EA. 1992. Fire and vegetation dynamics. Cambridge: Cambridge University Press.

Johnson EA, Wowchuk DR. 1993. Wildfires in the southern Canadian Rocky Mountains and their relationship to midtropospheric anomalies. Can J For Res 23:1213-22.

Kaiser J, editor. 1996. Gulf's 'dead zone' worries agencies. Science 274:331.

Kimmerer WJ , Gartside E, Orsi JJ . 1994. Predation by an introduced dam as the likely cause of substantial dedines in zooplankton of San Francisco Bay. Mar Ecol Prog Ser 223:81-93.

Knox J L, Lawford RG. 1990. The relationship between Canadian dry and wet months and circulation anomalies in the midtroposphere. Atmos Ocean 28:189-215.

Lewontin RC. 1969. The meaning of stability. Brookhaven Symp Biol 22:13-24.

Linden E. 1996 J ul 8. Global fever. Time 56-7.

Morris WF, Wood DM. 1989. The role of lupine in succession on Mount St. Helens: facilitation or inhibition? Ecology 70:697703.

Moyle PB, Herbold B, Stevens DE, Miller LW. 1992. Life history and status of delta smelt in the Sacramento-San J oaquin estuary, California. Trans Am Fish Soc 121:67-77.

Munich Re. 1996. Annual review of natural catastrophes 1995. Munich: Munchener Ruckversicherungs-Gesellschaft. $15 \mathrm{p}$.

Newark MJ . 1975. The relationship between forest fire occurrence and 500 millibar longwave ridging. Atmosphere 13:26-33.

Nichols FH, Cloern JE, Luoma SN, Peterson DH. 1986. The modification of an estuary. Science 231:569-73.

Nichols FH, Thompson JK, Schemel LE. 1990. Remarkable invasion of San Francisco Bay (California, USA) by the Asian clam Potamocorbula amurensis. II. Displacement of a former community. Mar Ecol Prog Ser 66:95-101.

NOAA. 1993. Our living oceans: report on the status of living marine resources 1993. Washington (DC): US Department of Commerce; NOAA Technical Memo NMFS-F/SPO-15. p 1-156.

Paine RT. 1988. Habitat suitability and local population persistence of the sea palm Postelsia palmaeformis. Ecology 69:1787-94.

Pickett STA, White PS. 1985. The ecology of natural disturbance and patch dynamics. New York: Academic.

Rabalais NN, Turner RE, Wiseman Jr WJ, Boesch DF. 1991. A brief summary of hypoxia on the northern Gulf of Mexico continental shelf: 1985-1988. In: Tyson RV, Pearson TH, editors. Modern and ancient continental shelf anoxia. p 35-47. (Geological Society Special Publication 58.)

Roemmich D, McGowan J. 1995. Climatic warming and the decline of zooplankton in the California Current. Science 267:1324-6.

Rogers J C. 1981. The North Pacific Oscillation. J Climatol 1:39-57.

Schowalter TD. 1985. Adaptations of insects to disturbance. In: Pickett STA, White PS, editors. The ecology of natural disturbance and patch dynamics. New York: Academic. p 235-52.

Schroeder MJ, Glovinsky M, Hendricks VH, and others. 1964. Synoptic weather types associated with critical fire weather. Berkeley (CA): USDA Forest Service, Pacific Southwest Forest and Range Experimental Station.

Sinclair ARE. 1977. The African buffalo. Chicago: University of Chicago Press.

Stone R. 1998. Yellowstone rising again from ashes of devastating fires. Science 280:1527-8. 
Street RB, Birch EC. 1986. Synoptic fire climatology of the Lake Athabasca-Great Slave Lake Area, 1977-1982. Climatol Bull 20:3-18.

Sutherland JP. 1974. Multiple stable points in natural communities. Am Nat 108:859-73.

Swetnam TW, Betancourt JL. 1990. Fire-southern oscillation relations in the southwestern United States. Science 249:101720.

Tegner MJ, Dayton PK. 1987. El Niño effects on Southern California kelp forest communities. Adv Ecol Res 17:243-79.

Trenberth KE. 1995. Northern Hemisphere climate change: physical processes and observed changes. In: Mooney HA, Fuentes ER, and Kronberg BI, editors. Earth system responses to global change. San Diego (CA): Academic. p 35-59.

Turner MG, Dale VH, Everham III EH. 1997. Crown fires, hurricanes, and volcanoes: a comparison among large-scale disturbances. BioScience 47:758-68.

Turner RE, Rabalais NN. 1994. Coastal eutrophication near the Mississippi River Delta. Nature 368:619-21.

Vanderhill BG. 1958. Observations in the pioneer fringe of western Canada. J Geogr 57:431-41.

Vitousek PM. 1990. Biological invasions and ecosystem processes: towards an integration of population biology and ecosystem studies. Oikos 57:7-13.
Vitousek PM, Walker LR. 1989. Biological invasion by Myrica fava in Hawaii: plant demography, nitrogen fixation, ecosystem effects. Ecol Monogr 59:247-65.

Wallace J M, Gutzler DS. 1981. Teleconnections in the geopotential height field during the Northern Hemisphere winter. Mon Weather Rev 109:784-812.

Weir JMH. 1996. The fire frequency and age mosaic of a mixedwood boreal forest [MSci thesis]. Calgary: University of Calgary.

White PS, Pickett STA. 1985. Natural disturbance and patch dynamics: an introduction. In: Pickett STA, White PS, editors. The ecology of natural disturbance and patch dynamics. New York: Academic. p 3-13.

Woodly JD, Chornesky EA, Clifford PA, Jackson JBC, Kaufman LS, Knowlton N, Lang J C, Pearson MP, Porter JW, Rooney KW, Rylaarsdam KW, and others. 1981. Hurricane Allen's impact on J amaican coral reefs. Science 214:749-55.

Woodward SA, Vitousek PM, Matson K, Hughes F, Benvenuto K, Matson PA. 1990. Use of the exotic tree Myrica fava by native and exotic birds in Hawaii Volcanoes National Park. Pac Sci 44:88-93.

Zedler PH, Gautier CR, McMaster GS. 1983. Vegetation change in response to extreme events: the effect of a short interval between fires in California chapparal and coastal scrub. Ecology $64: 809-18$. 